Article

\title{
Grafting Improves Fruit Yield of Cucumber Plants Grown under Combined Heat and Soil Salinity Stresses
}

\author{
Yousry Bayoumi ${ }^{1,2}{ }^{,}$Emad Abd-Alkarim ${ }^{1}$, Hassan El-Ramady ${ }^{3}{ }^{\mathbb{D}}$, Farouk El-Aidy ${ }^{1}$, El-Samahy Hamed ${ }^{4}$, \\ Naglaa Taha ${ }^{5}$, Jaime Prohens ${ }^{6, *(D)}$ and Mohamed Rakha ${ }^{1,2, *}$
}

1 Horticulture Department, Faculty of Agriculture, University of Kafrelsheikh, Kafr El-Sheikh 33516, Egypt; yousry.bayoumy@agr.kfs.edu.eg (Y.B.); emadbassuniy2014@gmail.com (E.A.-A.); farouk.elaidi@agr.kfs.edu.eg (F.E.-A.)

2 Physiology \& Breeding of Horticultural Crops Laboratory, Horticulture Department, Faculty of Agriculture, University of Kafrelsheikh, Kafr El-Sheikh 33516, Egypt

3 Soil and Water Department, Faculty of Agriculture, University of Kafrelsheikh, Kafr El-Sheikh 33516, Egypt; hassan.elramady@agr.kfs.edu.eg

4 Agriculture Research Center, Vegetable Crops Department, Horticulture Institute, Giza 12619, Egypt; elsamahyhamed@gmail.com

5 Agriculture Research Center, Plant Pathology Research Institute, Giza 12619, Egypt; naglaa_abdelbaset@yahoo.com

6 Instituto de Conservación y Mejora de la Agrodiversidad Valenciana, Universitat Politècnica de València, 46022 Valencia, Spain

* Correspondence: jprohens@btc.upv.es (J.P.); mohamed.rakha@agr.kfs.edu.eg (M.R.); Tel.: +34-96-387-9424 (J.P.); +20-155-311-0804 (M.R.)

check for updates

Citation: Bayoumi, Y.; Abd-Alkarim, E.; El-Ramady, H.; El-Aidy, F.; Hamed, E.-S.; Taha, N.; Prohens, J.; Rakha, M. Grafting Improves Fruit Yield of Cucumber Plants Grown under Combined Heat and Soil Salinity Stresses. Horticulturae 2021, 7, 61. https://doi.org/10.3390/

horticulturae7030061

Academic Editor: Federica Caradonia

Received: 27 February 2021

Accepted: 19 March 2021

Published: 23 March 2021

Publisher's Note: MDPI stays neutral with regard to jurisdictional claims in published maps and institutional affiliations.

Copyright: (c) 2021 by the authors Licensee MDPI, Basel, Switzerland. This article is an open access article distributed under the terms and conditions of the Creative Commons Attribution (CC BY) license (https:// creativecommons.org/licenses/by/ $4.0 /)$.
Abstract: Improving the productivity of cucumber (Cucumis sativus L.) plants subjected to combined salinity and heat stresses is a significant challenge, particularly in arid and semi-arid regions. Gianco F1 cucumbers were grafted onto five cucurbit rootstocks and, together with an ungrafted control, were grown in Egypt in a net house with saline soil during the summer season over two years. The vegetative growth, yield, quality, biochemical, and mineral composition traits were measured. Although many differences were observed among treatments, in general, the grafted plants had a performance better than or similar to that of the ungrafted plants, based on the different parameters measured. In particular, the cucumber plants grafted onto the Cucurbita maxima $\times$ C. moschata interspecific hybrid rootstocks VSS-61 F1 and Ferro had the highest early and total marketable yields. These two rootstocks consistently conferred higher vigor to the scion, which had lower flower abortion rates and higher chlorophyll contents. The fruit quality and $\mathrm{N}, \mathrm{P}$, and $\mathrm{K}$ composition in the leaves suffered few relevant changes as compared with the control. However, the leaves of the VSS-61 F1 had higher catalase activity, as well as proline and Se contents, while those of Ferro had higher Si content. This study reveals that the grafting of cucumber plants onto suitable rootstocks may mitigate the adverse effects caused by the combination of saline soil and heat stresses. This represents a significant improvement for cucumber cultivation in saline soil under high-temperature stress conditions in arid regions.

Keywords: abiotic stress; antioxidants; catalase; Cucumis sativus; peroxidase; proline; rootstocks

\section{Introduction}

Cucumber (Cucumis satious L.) is an important horticultural crop, since it is one of the major vegetables grown in greenhouses worldwide [1]. Although cucumber is a thermophilic vegetable crop, it is sensitive to heat stress [2]. The production of cucumber in greenhouses faces some abiotic stresses, particularly in arid regions, due to excessive application of mineral fertilizers, use of brackish water, soil salinization, and high temperatures in the summer $[3,4]$. These stresses are expected to be intensified because of climate 
change; under these conditions, the resulting imbalances in plant hormones, nutrition, and physiological disorders may also contribute to an increase in biotic stresses [5].

Abiotic stresses cause significant losses in global crop production. Several abiotic stresses have been studied in cucumber, including alkalinity stress [6], drought [7], salinity $[8,9]$, and heat stress [2,10]; however, these studies have focused on a single stress, while global environmental changes cause multiple stresses in various combinations [11,12]. To the best of our knowledge, no studies have investigated the impact of multiple stresses, in particular, the combined effect of soil salinity and heat stress on the yield of cucumber plants in arid regions.

Plants, as sessile organisms, have gradually developed defense systems to modulate environmental stresses [13]. In addition, several agricultural practices have contributed to adaptation to environmental stresses [14]. One of the approaches used in agriculture to overcome abiotic stresses is grafting [15]. Grafting is considered to be one of the most important agronomic techniques, which could save time and costs in breeding programs [16]. The most common grafted vegetables include watermelon, melon, tomato, cucumber, pepper, and eggplant [17]. Grafting of cucumber plants is a common practice, by which the tolerance to stresses of cultivars used as scion are improved using rootstocks that are tolerant to abiotic stresses such as salinity $[8,18,19]$, water stress [20], or heat stress [2]. In addition, grafting of cucumber plants may also increase plant vigor and enhance the uptake of water and nutrients [21].

Soil salinity is considered to be one of the most important abiotic stresses, with a global increase of $26 \%$ from 2000 to 2016 in areas affected by soil salinity, resulting in over 1 billion hectares currently affected, mostly situated in arid regions [22]. In cucumber plants, salinity stress causes a growth reduction, toxicity in the leaves, and increases membrane permeability and electrolyte leakage, and therefore, results in a reduction in both the yield and the quality of fruit [23-25]. Heat stress is an important global issue, with over 1.7 billion hectares presently affected [26], and a steady increase in areas affected due to rising atmospheric temperatures. The increased greenhouse production of cucumbers during the summer in warm arid regions has potentially contributed to increasing the occurrence of high temperature stress. In cucumber plants, heat stress induces important changes in gene expression [27], as well as negative effects at the physiological level, including a reduction in photosynthetic functions, a reduction in water and nutrient uptake, and increased respiration [28], which in turn impact growth and yield. In agriculture, combined stresses frequently occur [29]; in this regard, high temperatures often coexist with soil salinity in several areas worldwide [30]. Despite the importance of combined salinity and heat stresses in vegetables, there is a lack of studies on cucumber plants' responses to this combination of stresses and on the potential of grafting for overcoming the impact of stresses on this crop. Apart from the evaluation of growth and development traits, several antioxidant enzymes, such as catalase and peroxidase, play a main role in reducing oxidative damage caused by stress [31]. In addition, osmolytes such as proline are known to be involved in maintaining the osmotic balance under salinity stress [32].

The aim of this study was to evaluate the growth, yield, physiological, biochemical, and mineral composition parameters in cucumber plants grafted onto five cucurbit rootstocks grown under combined salinity and heat stresses. The results obtained provide relevant information for improving the production of cucumber under these conditions.

\section{Materials and Methods}

\subsection{Plant Material}

Cucumber hybrid Gianco F1 (Rijk Zwaan Agro Company, Cairo, Egypt) was used as a scion in this study. This hybrid is gynoecious and produces parthenocarpic fruits with smooth green skin. Five cucurbit rootstocks (Ferro, Cobalt, VSS-61 F1, Bottle gourd, and Super Shintoza) were selected for study (Table 1) along with the ungrafted control Gianco F1. These rootstock cultivars were chosen because they are among the most popular for cucumber grafting in the area where the experiments were performed. All of these 
rootstocks are resistant to Fusarium wilt and have also been reported to provide resistance or tolerance to other biotic or abiotic stresses (Table 1). Cucumber seeds (Gianco F1 control) and five cucurbit rootstocks were sown by mid-April in seedling foam trays (84 cells) which were filled with a mixture of peat moss/vermiculite $(1: 1 \mathrm{v} / \mathrm{v})$ in a net house. The grafting was performed using slant cut grafting (i.e., splice grafting) 30 days after sowing.

Table 1. Description of the cucurbit rootstocks used for grafting cucumber plants under combined heat and soil salinity stresses.

\begin{tabular}{|c|c|c|c|}
\hline Rootstock Name & Rootstock Species & Characteristics & Seed Source \\
\hline Ferro & Cucurbita maxima $\times$ C. moschata & $\begin{array}{c}\text { Resistant to Fusarium wilt and } \\
\text { Verticillium wilt }\end{array}$ & $\begin{array}{c}\text { Rijk Zwaan Agro Company, } \\
\text { Cairo, Egypt }\end{array}$ \\
\hline Cobalt & C. maxima $\times$ C. moschata & $\begin{array}{l}\text { Resistant to Fusarium wilt and } \\
\text { tolerant to low and } \\
\text { high temperatures }\end{array}$ & $\begin{array}{l}\text { Rijk Zwaan Agro Company, } \\
\text { Cairo, Egypt }\end{array}$ \\
\hline VSS-61 F1 & Cucurbita pepo (squash) & $\begin{array}{l}\text { Resistant to Fusarium wilt } \\
\text { and nematode }\end{array}$ & $\begin{array}{l}\text { Meroe seeds, } \\
\text { Techno Green Seed Company, } \\
\text { Cairo, Egypt }\end{array}$ \\
\hline Bottle gourd & Lagenaria siceraria & $\begin{array}{l}\text { Resistant to Fusarium wilt and } \\
\text { tolerant to low temperatures }\end{array}$ & $\begin{array}{c}\text { El-Nada and El-Nour Company, } \\
\text { Nubaria, Egypt }\end{array}$ \\
\hline Super Shintoza & C. maxima $\times$ C. moschata & $\begin{array}{l}\text { Resistant to Fusarium wilt and } \\
\text { tolerant to low and } \\
\text { high temperatures }\end{array}$ & $\begin{array}{l}\text { G.S.I. Exports Seed Company, } \\
\text { Amsterdam, The Netherlands }\end{array}$ \\
\hline
\end{tabular}

\subsection{Growing Conditions and Experimental Design}

The experiments were conducted for two years (2017 and 2018), from May to August, to align with the highest summer temperatures in Egypt. The two experiments were conducted at the experimental farm for protected cultivation, Faculty of Agriculture, Kafrelsheikh University, Egypt $\left(31^{\circ} 05^{\prime} 54^{\prime \prime} \mathrm{N}\right.$ and $\left.30^{\circ} 57^{\prime} 00^{\prime \prime} \mathrm{E}\right)$.

The successfully grafted cucumber and the control (ungrafted) seedlings were transplanted into a Spanish-style net house. The width and length of this net house was $9 \mathrm{~m}$ and $30 \mathrm{~m}$, respectively. The height in the middle part of the transversal section was $3.5 \mathrm{~m}$. Each experimental plot consisted of two rows that were $10 \mathrm{~m}$ long and spaced $1.5 \mathrm{~m}$. Plant spacing within the rows was $50 \mathrm{~cm}$, resulting in 40 plants per plot. The mean daily maximum temperatures (at $2 \mathrm{~m}$ from the ground) in the net house during the experimental period were $35.1{ }^{\circ} \mathrm{C}$ (2017) and $36.9^{\circ} \mathrm{C}$ (2018). Salinity stress was applied by growing the seedlings in soil affected by salinity (Electrical Conductivity $=4.49 \mathrm{dS} \mathrm{m}^{-1}, \mathrm{pH}=8.65$ ). The transplants were watered daily and fertilized twice a week with the recommended nutrient concentration levels through a drip irrigation system using a venture injector from the 1st week of transplanting up to the 14th week. The applied fertilizers included $\mathrm{N}, \mathrm{P}_{2} \mathrm{O}_{5}$, and $\mathrm{K}_{2} \mathrm{O}\left(22,15\right.$, and $25 \mathrm{~kg}$ per $540 \mathrm{~m}^{2}$, respectively) as well as $\mathrm{Ca}, \mathrm{Mg}, \mathrm{Fe}, \mathrm{Zn}$, and $\mathrm{Mn}$, applied in the recommended doses depending on the growth stage through the drip system according to the recommendations of the Ministry of Agriculture and Land Reclamation of Egypt. Cucumber plants were trained vertically to an overhead wire. Once the plants reached the wire they were topped, and then pruned using an umbrella system. Other horticultural practices were performed, according to the recommendations of the Egyptian Ministry of Agriculture and Land Reclamation of Egypt. For each of the two years, the experiments were arranged in a randomized complete block design with three replicates, totaling 120 plants per treatment (40 per replicate) and 720 plants per year. 


\subsection{Vegetative Growth, Fruit, and Yield Traits}

The vegetative growth parameters, including plant height $(\mathrm{cm})$ and leaf area per plant $\left(\mathrm{dm}^{2}\right)$, were measured at 30,50, and 70 days after transplanting (DAT) on five random plants per experimental plot. For both years, all plots were harvested, starting from the middle of June, to measure the early and total yields. The early yield was calculated on the basis of the first 10 harvests for the first 3 weeks of harvesting, and harvesting was continued for 2 months. The fruit weight and total yield are presented here on a per square meter basis. Cucumber fruits at a marketable stage, characterized by being physiologically unripe, with a fruit length between 14 and $17 \mathrm{~cm}$, a diameter between 2.6 and $3.0 \mathrm{~cm}$, immature seeds, and bright epidermis were harvested, as described by Sevgican [33], and were then categorized in order to obtain the marketable and unmarketable yield. The quality of cucumber fruits was analyzed using fruit firmness $\left(\mathrm{g} \mathrm{cm}^{-2}\right)$ and total soluble solids (TSS) at 30, 50, and 70 DAT. Additionally, 10 fruits per replication were selected for fruit quality analysis. The abortion rate per plant was calculated at the same DAT.

\subsection{Chlorophyll, Enzymatic Antioxidants, Proline, and Electrolyte Leakage}

Leaf chlorophyll content was measured using a soil plant analysis development (SPAD) chlorophyll meter (Konica-Minolta, Osaka, Japan) on fully expanded leaves without destroying them at 30, 50, and 70 DAT. Peroxidase (POD) and catalase (CAT) enzyme activities were colorimetrically measured in the 3rd fully expanded cucumber leaf tip at 70 DAT, according to Upadhyaya et al. [34] for POD and Rao et al. [35] for CAT. Proline was determined at 70 DAT, according to the method described by Bates et al. [36]. The electrolyte leakage (EL) of the cucumber leaves was measured using an electrical conductivity meter at 70 DAT (only in 2018), according to Lutts et al. [37]. All these parameters were measured at the Plant Pathology and Biotechnology Lab (accredited according to ISO/17025), Department of Agricultural Botany, Faculty of Agriculture, Kafrelsheikh University, Egypt.

\subsection{Mineral Concentrations}

At 70 days from sowing, the concentrations of leaf N, P, K, Si, and Se were measured. The nitrogen, phosphorus, and potassium contents, as well as silicon [38] and selenium contents [39], were measured in digested plant leaves using the micro-Kjeldahl method (UDK 159, Velp Scientifica, Usmate, Italy) for N, using a spectrophotometer (Libra S80PC, Biochrom, Cambridge, UK) for $\mathrm{P}$ and $\mathrm{Si}$, and using an inductively coupled plasma-optical emission spectrometry (ICP-OES) apparatus (Prodigy 7, Leeman Labs., Hudson, NH, USA) for measuring Se and $\mathrm{K}$. Leaves were dried at $70{ }^{\circ} \mathrm{C}$ until they reached a constant weight, and then ground and wet digested using sulfuric acid and hydrogen peroxide. The measurement of mineral concentrations was carried out at the Central Laboratory of Environmental Studies, Kafrelsheikh University, Kafrelsheikh, Egypt.

\subsection{Statistical Analyses}

All the obtained data during both seasons of study were tabulated and subjected to an analysis of variance [40] using the "M-STAT" computer software package Version 5.4 (M-STAT SA, Athens, Greece). Mean separation was performed with Duncan's multiple range tests at $p=0.05$.

\section{Results}

\subsection{Vegetative Growth}

As expected, given the rootstocks' resistance to Fusarium, no symptoms of Fusarium wilt were observed during the experiments. Plant height and leaf area were generally higher in the grafted plants, as compared with the control plants, from 30 to 70 DAT during all the growth periods (Table 2). At the end of the experiment, the plant height and leaf area of the ungrafted plants (control) had the lowest values among all the treatments in both 2017 and 2018 (plant heights of 244 and $267 \mathrm{~cm}$ and leaf areas of 65.4 and $83.42 \mathrm{dm}^{-2}$, respectively); on the other hand, the grafted rootstock VSS-61 F1 recorded the highest 
values at 70 DAT in 2017 and 2018 (plant heights of 324 and $368 \mathrm{~cm}$ and leaf areas of 83.40 and $96.53 \mathrm{dm}^{-2}$, respectively), with values significantly higher than those of the control at all dates and for both traits (Table 2).

Table 2. Mean values for plant height and leaf area of Gianco F1 cucumber plants grafted onto five cucurbit rootstocks and the ungrafted control at 30, 50, and 70 days after transplanting (DAT) under heat and salinity stresses in the 2017 and 2018 seasons. Details on the measurement of the traits presented are provided in the Material and Methods Section.

\begin{tabular}{|c|c|c|c|c|c|c|}
\hline \multirow[b]{2}{*}{ Rootstock } & \multicolumn{3}{|c|}{2017} & \multicolumn{3}{|c|}{2018} \\
\hline & 30 DAT & 50 DAT & 70 DAT & 30 DAT & 50 DAT & $70 \mathrm{DAT}$ \\
\hline \multicolumn{7}{|c|}{ Plant height $(\mathrm{cm})^{a}$} \\
\hline Control (ungrafted) & $111 \mathrm{c}$ & $152 \mathrm{~b}$ & $244 \mathrm{~b}$ & $105 c$ & $203 \mathrm{~b}$ & $267 \mathrm{~b}$ \\
\hline Ferro & $163 \mathrm{a}$ & $213 \mathrm{a}$ & $286 \mathrm{ab}$ & 129 a & $224 \mathrm{ab}$ & $345 \mathrm{a}$ \\
\hline VSS-61 F1 & $140 \mathrm{ab}$ & $197 \mathrm{a}$ & $324 \mathrm{a}$ & $124 \mathrm{ab}$ & $211 b$ & $368 \mathrm{a}$ \\
\hline Cobalt & 156 a & $227 \mathrm{a}$ & $274 \mathrm{ab}$ & $111 \mathrm{bc}$ & $204 \mathrm{~b}$ & $325 \mathrm{a}$ \\
\hline Bottle gourd & $145 \mathrm{ab}$ & $218 \mathrm{a}$ & $264 \mathrm{ab}$ & $112 \mathrm{bc}$ & $224 \mathrm{ab}$ & $339 \mathrm{a}$ \\
\hline Super Shintoza & $123 \mathrm{bc}$ & $219 \mathrm{a}$ & $313 \mathrm{ab}$ & $116 \mathrm{bc}$ & 248 a & $343 \mathrm{a}$ \\
\hline Prob. $\mathrm{F}^{\mathrm{b}}$ & $* *$ & $* *$ & ** & ** & $* *$ & $* *$ \\
\hline \multicolumn{7}{|c|}{ Leaf area $\left(\mathrm{dm}^{2} \text { plant }^{-1}\right)^{a}$} \\
\hline Control (ungrafted) & $37.40 \mathrm{~b}$ & $45.23 \mathrm{~b}$ & $65.40 c$ & $33.97 \mathrm{~b}$ & $63.35 \mathrm{~b}$ & $83.42 \mathrm{~b}$ \\
\hline Ferro & $40.82 \mathrm{a}$ & $61.52 \mathrm{a}$ & $82.11 \mathrm{a}$ & $38.12 \mathrm{ab}$ & $83.27 \mathrm{a}$ & $91.76 \mathrm{ab}$ \\
\hline VSS-61 F1 & $38.14 \mathrm{ab}$ & $64.64 \mathrm{a}$ & $83.40 \mathrm{a}$ & $39.56 \mathrm{a}$ & $76.02 \mathrm{ab}$ & $96.53 \mathrm{a}$ \\
\hline Cobalt & $40.11 \mathrm{ab}$ & $59.05 \mathrm{a}$ & $76.55 \mathrm{ab}$ & $39.52 \mathrm{a}$ & $71.13 \mathrm{ab}$ & $88.64 \mathrm{ab}$ \\
\hline Bottle gourd & $37.63 \mathrm{~b}$ & $55.13 \mathrm{ab}$ & $72.46 \mathrm{bc}$ & $34.93 \mathrm{ab}$ & $74.32 \mathrm{ab}$ & $85.21 \mathrm{ab}$ \\
\hline Super Shintoza & $38.63 \mathrm{ab}$ & $64.23 \mathrm{a}$ & $79.64 \mathrm{ab}$ & $37.53 \mathrm{ab}$ & $76.84 \mathrm{ab}$ & $91.75 \mathrm{ab}$ \\
\hline Prob. $\mathrm{F}^{\mathrm{b}}$ & * & $* *$ & $* *$ & $* *$ & * & * \\
\hline
\end{tabular}

${ }^{a}$ Different letters in the same column indicate significant differences between treatments according to Duncan's test at $p<0.05$. ${ }^{*}, * *$ indicate significant at $p$ values $<0.05$, and $<0.01$, respectively.

\subsection{Yield and Fruit Quality}

The plants grafted onto some rootstocks had lower abortion rates than the ungrafted control at most dates (Table 3). We observed that plants grafted onto VSS-61 F1 had lower abortion rates than the control in 2017 at 30 DAT, and at all DAT in 2018, while those grafted onto Ferro displayed the same results, except at 70 DAT in 2018, in which no significant differences were observed as compared with the control. Plants grafted onto Super Shintoza displayed higher abortion rates than the control at 30 DAT in both years (Table 3). For fruit firmness, although significant differences among treatments were observed in 2017, none of the rootstocks conferred consistently higher firmness than the control across the three DATs. In 2018, there were no significant differences among treatments in firmness (Table 3). For soluble solid contents, all rootstocks conferred higher values at 30 DAT in 2017, and only Ferro and VSS-61 F1 conferred higher values at 70 DAT in 2018. For the remaining dates, no significant differences were observed (Table 3). 
Table 3. Means of the abortion rate per plant, fruit firmness, and total soluble solids of Gianco F1 cucumber plants, grafted onto five cucurbit rootstocks and the ungrafted control, under heat and salinity stresses in the 2017 and 2018 seasons. Details on the measurement of the traits presented are provided in the Material and Methods Section.

\begin{tabular}{|c|c|c|c|c|c|c|}
\hline \multirow[b]{2}{*}{ Rootstock } & \multicolumn{3}{|c|}{2017} & \multicolumn{3}{|c|}{2018} \\
\hline & 30 DAT & 50 DAT & 70 DAT & 30 DAT & 50 DAT & 70 DAT \\
\hline \multicolumn{7}{|c|}{ Abortion rate $(\%)^{a}$} \\
\hline Control (ungrafted) & $2.46 \mathrm{~b}$ & 10.68 & 18.18 & $2.78 \mathrm{~b}$ & $10.76 \mathrm{ab}$ & $20.76 \mathrm{ab}$ \\
\hline Ferro & $1.15 \mathrm{c}$ & 10.90 & 18.91 & $1.49 \mathrm{c}$ & $7.16 \mathrm{c}$ & $15.44 \mathrm{bc}$ \\
\hline VSS-61 F1 & $1.20 \mathrm{c}$ & 10.86 & 18.15 & $1.67 \mathrm{c}$ & $6.62 c$ & $13.89 \mathrm{c}$ \\
\hline Cobalt & $2.65 \mathrm{~b}$ & 11.16 & 20.77 & $2.34 \mathrm{ab}$ & $7.40 \mathrm{bc}$ & $15.43 \mathrm{bc}$ \\
\hline Bottle gourd & $2.60 \mathrm{~b}$ & 10.21 & 18.25 & $2.36 \mathrm{ab}$ & $9.42 \mathrm{abc}$ & $18.08 \mathrm{abc}$ \\
\hline Super Shintoza & $3.75 \mathrm{a}$ & 11.12 & 20.16 & $2.84 \mathrm{a}$ & $11.84 \mathrm{a}$ & $22.44 \mathrm{a}$ \\
\hline Prob. $\mathrm{F}^{\mathrm{b}}$ & $* *$ & ns & ns & $*$ & $* *$ & $* *$ \\
\hline \multicolumn{7}{|c|}{ Fruit firmness $\left(\mathrm{g} \mathrm{cm}^{-2}\right)^{a}$} \\
\hline Control (ungrafted) & $430 \mathrm{a}$ & $491 \mathrm{~b}$ & $423 \mathrm{c}$ & 447 & 421 & 407 \\
\hline Ferro & $369 c$ & $540 \mathrm{ab}$ & $450 \mathrm{abc}$ & 435 & 417 & 427 \\
\hline VSS-61 F1 & $384 \mathrm{bc}$ & $555 \mathrm{a}$ & $469 \mathrm{a}$ & 447 & 457 & 444 \\
\hline Cobalt & $334 \mathrm{a}$ & $524 \mathrm{ab}$ & $460 \mathrm{ab}$ & 421 & 441 & 423 \\
\hline Bottle gourd & $431 \mathrm{ab}$ & $524 \mathrm{ab}$ & $434 \mathrm{bc}$ & 435 & 388 & 423 \\
\hline Super Shintoza & $417 \mathrm{ab}$ & $401 \mathrm{c}$ & $450 \mathrm{abc}$ & 477 & 416 & 437 \\
\hline Prob. $\mathrm{F}^{\mathrm{b}}$ & $*$ & $* *$ & $* *$ & ns & ns & ns \\
\hline \multicolumn{7}{|c|}{ Total soluble solids (\%) ${ }^{a}$} \\
\hline Control (ungrafted) & $3.06 \mathrm{c}$ & 2.93 & 3.21 & 3.27 & 3.31 & $3.11 \mathrm{~b}$ \\
\hline Ferro & $3.38 \mathrm{ab}$ & 3.07 & 3.25 & 3.47 & 3.47 & $3.51 \mathrm{a}$ \\
\hline VSS-61 F1 & $3.45 \mathrm{a}$ & 2.95 & 3.53 & 3.67 & 3.34 & $3.60 \mathrm{a}$ \\
\hline Cobalt & $3.34 \mathrm{ab}$ & 3.10 & 3.32 & 3.62 & 3.58 & $3.20 \mathrm{ab}$ \\
\hline Bottle gourd & $3.41 \mathrm{ab}$ & 3.02 & 3.32 & 3.63 & 3.37 & $3.39 \mathrm{ab}$ \\
\hline Super Shintoza & $3.29 \mathrm{~b}$ & 3.22 & 3.31 & 3.45 & 3.53 & $3.39 \mathrm{ab}$ \\
\hline Prob. $\mathrm{F}^{\mathrm{b}}$ & $* *$ & ns & ns & ns & ns & $*$ \\
\hline
\end{tabular}

${ }^{\mathrm{a}}$ Different letters in the same column indicate significant differences between treatments according to Duncan's test at $p<0.05 .{ }^{\mathrm{b}} \mathrm{ns},{ }^{*},{ }^{* *}$ indicate non-significant or significant at $p$ values $<0.05$, and $<0.01$, respectively.

Plants grafted onto Ferro had a significantly higher early yield than the control in 2017 and 2018 (Figure 1). The remaining rootstocks did not present significant differences as compared with the control in 2017, but all of them, except for the Bottle gourd, also resulted in a higher early yield than the control in 2018 (Figure 1). All rootstocks, except for the Bottle gourd, had a higher marketable yield than the control in both 2017 and 2018. In addition, the plants grafted onto Ferro and VSS-61 F1 had a higher marketable yield than Cobalt in 2018 (Figure 1). For the unmarketable fruit yield, no differences were observed in 2017, except that the unmarketable fruit yield of the plants grafted onto Super Shintoza was lower than the other treatments. However, in 2018, the plants grafted onto Ferro, VSS-61 F1, and Cobalt had unmarketable fruit yield values that were significantly lower than those of the control. 
(a) Early fruit yield

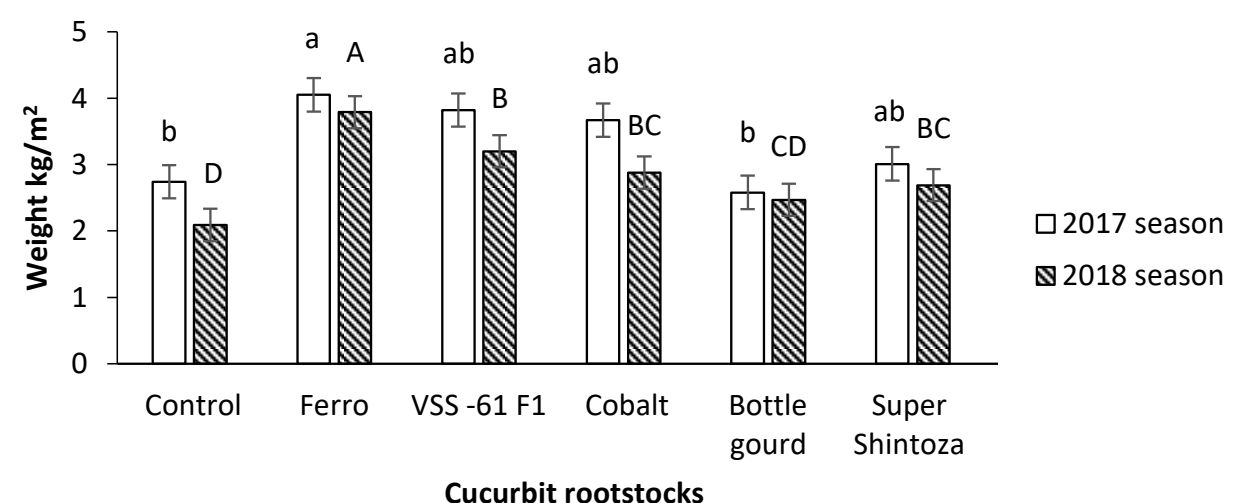

(b) Marketable fruit yield

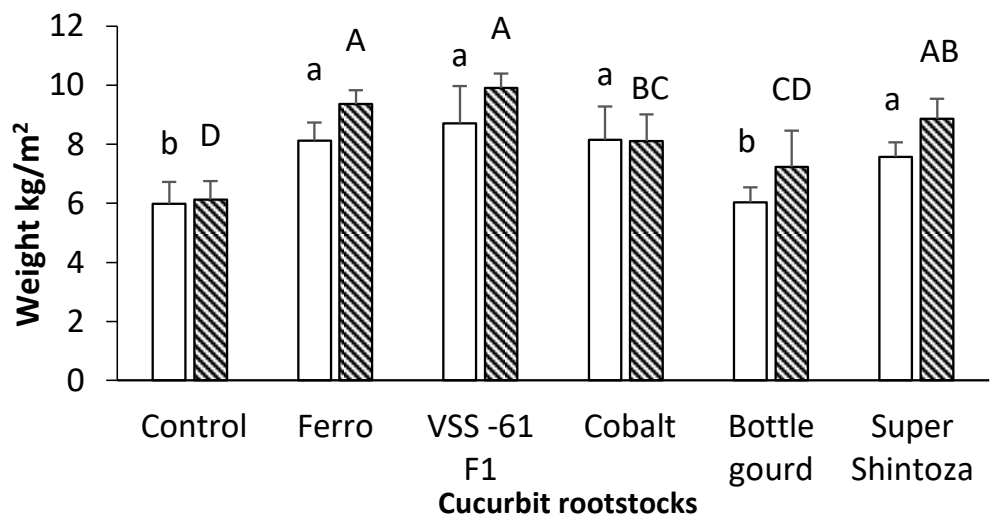

$\square 2017$ season

$\$ 2018$ season

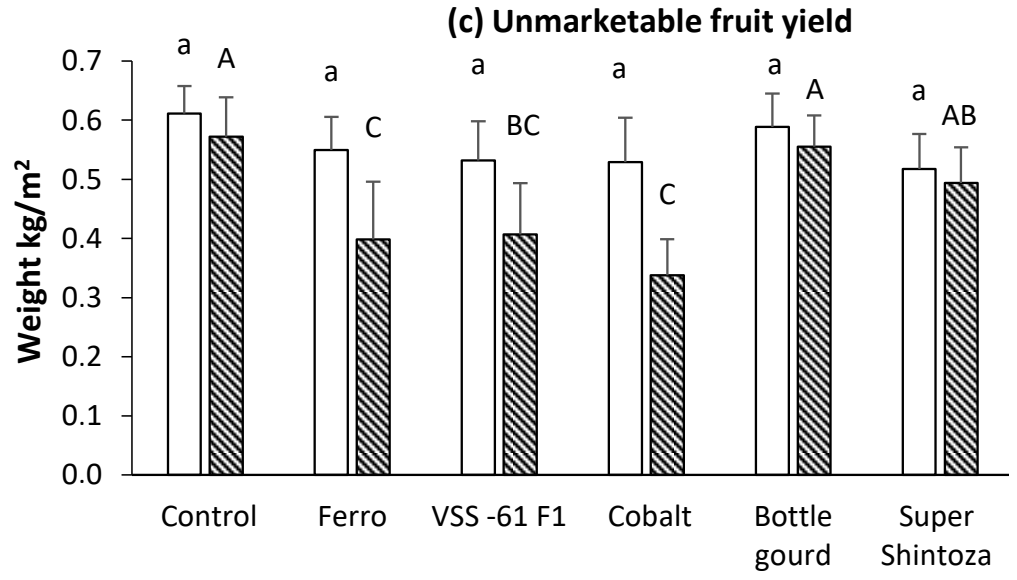

$\square 2017$ season

\$2018 season

Cucurbit rootstocks

Figure 1. (a) Early fruit yield, (b) marketable fruit yield, and (c) unmarketable fruit yield (mean \pm SD) of Gianco F1 cucumber plants grafted onto cucurbit rootstocks and the ungrafted control under soil salinity and heat stresses in the 2017 and 2018 seasons. For each season, different letters (lowercase for 2017 and uppercase for 2018) indicate significant differences between treatments according to Duncan's test at $p \leq 0.05$. Details on the measurement of the traits presented are provided in the Material and Methods Section.

\subsection{Chlorophyll, Enzymatic Antioxidants, Proline, and Electrolyte Leakage}

Chlorophyll content was affected by grafting (Table 4). Although there were no differences among treatments at 30 DAT in 2017 and 50 DAT in 2018, at 70 DAT the grafted plants had higher chlorophyll contents in both years (Table 4). The highest chlorophyll 
content was observed in the cucumber plants grafted on rootstock VSS-61 F1 in both years (40.09 and 39.66, respectively, at 70 DAT); however, there were no significant differences with the other rootstocks.

Table 4. Means of leaf chlorophyll content of Gianco F1 cucumber plants grafted onto five cucurbit rootstocks and the ungrafted control under heat and salinity stresses in the 2017 and 2018 seasons. Details on the measurement of the traits presented are provided in the Material and Methods Section.

\begin{tabular}{|c|c|c|c|c|c|c|}
\hline \multirow[b]{2}{*}{ Rootstock } & \multicolumn{3}{|c|}{2017} & \multicolumn{3}{|c|}{2018} \\
\hline & $30 \mathrm{DAT}$ & 50 DAT & 70 DAT & 30 DAT & 50 DAT & 70 DAT \\
\hline \multicolumn{7}{|c|}{ Chlorophyll content (SPAD units) $^{a}$} \\
\hline Control (ungrafted) & 39.47 & $39.07 \mathrm{~b}$ & $37.53 \mathrm{~b}$ & $35.60 \mathrm{~b}$ & 37.66 & $34.63 \mathrm{~b}$ \\
\hline Ferro & 39.48 & $39.46 \mathrm{ab}$ & $39.67 \mathrm{a}$ & $38.50 \mathrm{ab}$ & 37.63 & $37.65 \mathrm{ab}$ \\
\hline VSS-61 F1 & 39.74 & $40.54 \mathrm{a}$ & $40.09 \mathrm{a}$ & $37.33 \mathrm{ab}$ & 37.10 & $39.66 \mathrm{a}$ \\
\hline Cobalt & 39.75 & $39.82 \mathrm{ab}$ & $39.61 \mathrm{a}$ & $37.36 \mathrm{ab}$ & 39.71 & $38.63 \mathrm{ab}$ \\
\hline Bottle gourd & 39.44 & $39.29 \mathrm{~b}$ & $39.55 \mathrm{a}$ & $37.75 \mathrm{ab}$ & 38.94 & $36.70 \mathrm{ab}$ \\
\hline Super Shintoza & 39.29 & $39.24 \mathrm{~b}$ & $39.81 \mathrm{a}$ & $39.27 \mathrm{a}$ & 38.95 & $39.59 \mathrm{a}$ \\
\hline Prob. $\mathrm{F}^{\mathrm{b}}$ & ns & $*$ & $* *$ & $*$ & ns & $* *$ \\
\hline
\end{tabular}

${ }^{\mathrm{a}}$ Different letters in the same column indicate significant differences between treatments according to Duncan's test at $p<0.05 .{ }^{\mathrm{b}} \mathrm{ns},{ }^{*}, * *$ indicate non-significant or significant at $p$ values $<0.05$, and $<0.01$, respectively.

The levels of enzymatic antioxidants and proline were generally higher in several of the grafted cucumber rootstocks than in the ungrafted control, although there were differences in the pattern depending on the parameter measured, the year, and the treatment evaluated (Table 5). The results show that the values of catalase in grafted cucumbers were significantly higher than the ungrafted control for all rootstocks, except for Ferro in 2017, while in 2018, they were significantly higher only in VSS-61 F1. For peroxidase, Ferro and Bottle gourd had levels significantly higher than the ungrafted control in 2018, while in 2017, no significant differences were observed. Regarding proline, VSS-61 F1 and Bottle gourd had levels significantly higher than those of the ungrafted control in both years.

Table 5. Means of catalase and peroxidase activities $\left(\mathrm{mmol} \mathrm{H}_{2} \mathrm{O}_{2} \mathrm{~g}^{-1} \mathrm{FW} \mathrm{min}{ }^{-1}\right)$ and proline contents $\left(\mathrm{mg} \mathrm{kg}^{-1}\right.$ of fresh weight) in the leaves of Gianco F1 cucumber plants grafted onto five cucurbit rootstocks and the ungrafted control under heat and salinity stresses in the 2017 and 2018 seasons. Results are expressed as percentage over dry weight. Details on the measurement of the traits presented are provided in the Material and Methods Section.

\begin{tabular}{ccccccc}
\hline & \multicolumn{3}{c}{$\mathbf{2 0 1 7}^{\mathrm{a}}$} & & $\mathbf{2 0 1 8}^{\mathbf{a}}$ \\
\hline Rootstock & Catalase & Peroxidase & Proline & Catalase & Peroxidase & Proline \\
\hline Control (ungrafted) & $0.033 \mathrm{~b}$ & 0.080 & $0.16 \mathrm{~b}$ & $0.037 \mathrm{~b}$ & $0.070 \mathrm{~b}$ & $0.17 \mathrm{c}$ \\
Ferro & $0.036 \mathrm{ab}$ & 0.088 & $0.17 \mathrm{~b}$ & $0.043 \mathrm{ab}$ & $0.113 \mathrm{a}$ & $0.18 \mathrm{c}$ \\
VSS-61 F1 & $0.045 \mathrm{a}$ & 0.099 & $0.31 \mathrm{a}$ & $0.054 \mathrm{a}$ & $0.078 \mathrm{~b}$ & $0.29 \mathrm{~b}$ \\
Cobalt & $0.040 \mathrm{a}$ & 0.084 & $0.22 \mathrm{~b}$ & $0.040 \mathrm{ab}$ & $0.078 \mathrm{~b}$ & $0.20 \mathrm{c}$ \\
Bottle gourd & $0.041 \mathrm{a}$ & 0.104 & $0.37 \mathrm{a}$ & $0.040 \mathrm{ab}$ & $0.120 \mathrm{a}$ & $0.40 \mathrm{a}$ \\
Super Shintoza & $0.045 \mathrm{a}$ & 0.081 & $0.22 \mathrm{~b}$ & $0.038 \mathrm{ab}$ & $0.074 \mathrm{~b}$ & $0.20 \mathrm{c}$ \\
Prob. F & $*$ & $\mathrm{~ns}$ & $* *$ & $*$ & $* *$ \\
\hline
\end{tabular}

${ }^{a}$ Different letters in the same column indicate significant differences among each group of treatments according to Duncan's test at $p<0.05$.

${ }^{\mathrm{b}} \mathrm{ns},{ }^{*},{ }^{* *}$ indicate non-significant or significant at $p$ values $<0.05$, and $<0.01$, respectively.

For electrolyte leakage (EL), which was only measured in 2018, only Super Shintoza displayed significantly lower values than the ungrafted control. Cobalt and Bottle gourd also had significantly higher EL than Super Shintoza (Figure 2). 


\section{Electrolyte leakage}

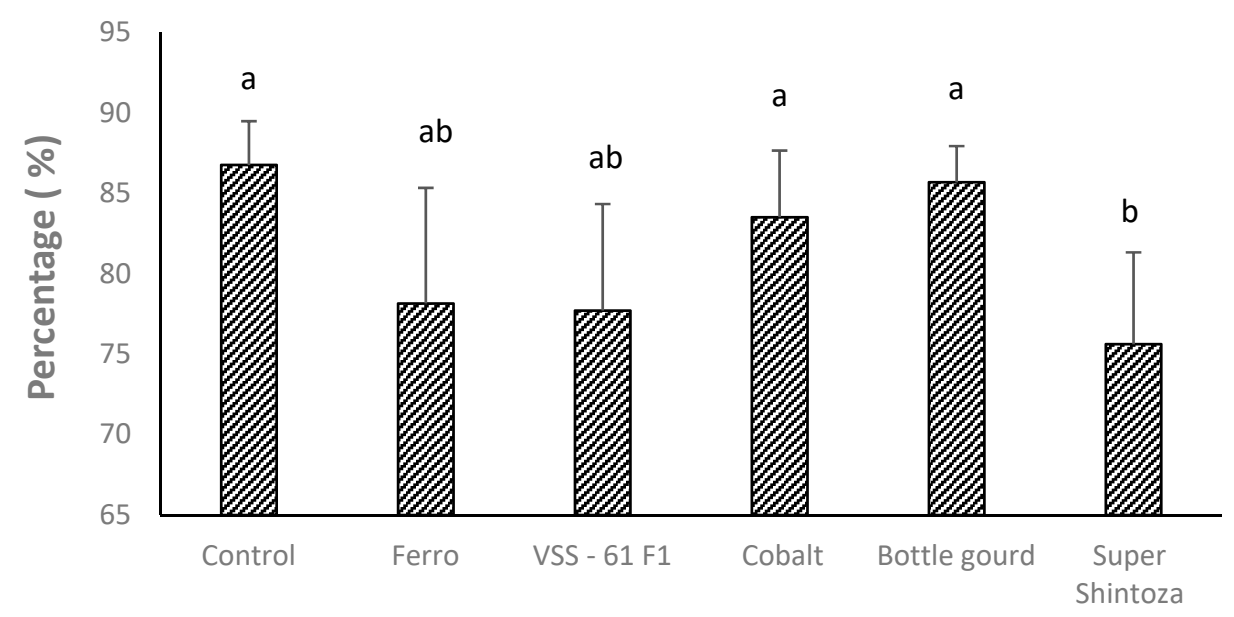

\section{Cucurbit rootstocks}

Figure 2. Percentage of leaf electrolyte leakage (mean \pm SD) of Gianco F1 cucumber plants grafted onto five cucurbit rootstocks and the ungrafted control under soil salinity and heat stresses in the 2018 season. Different letters indicate significant differences between treatments according to Duncan's test at $p<0.05$. Details on the measurement of the trait presented are provided in the Material and Methods Section.

\subsection{Mineral Composition}

Many differences were observed among the six treatments studied for the minerals analyzed in the leaf (N, P, K, Si, and Se). For N, plants grafted onto Super Shintoza and Bottle gourd had higher and lower levels, respectively, than the ungrafted control in 2017, while in 2018, no differences were observed between the control and any of the rootstocks (Table 6). For P, plants grafted onto Ferro had higher contents than the ungrafted control in 2017, but no differences were observed among the treatments in 2018. Regarding K, plants grafted onto Super Shintoza had higher contents than the ungrafted control in both years, and Ferro and Bottle gourd also had higher levels in 2018 (Table 6).

Table 6. Means of nitrogen $(\mathrm{N})$, phosphorus $(\mathrm{P})$, and potassium $(\mathrm{K})$ contents in the leaves of Gianco F1 cucumber plants grafted onto five cucurbit rootstocks and the ungrafted control under heat and salinity stresses in the 2017 and 2018 seasons. Results are expressed as a percentage over dry weight. Details on the measurement of the traits presented are provided in the Material and Methods Section.

\begin{tabular}{ccccccc}
\hline & \multicolumn{3}{c}{$\mathbf{2 0 1 7}^{\mathbf{a}}$} & \multicolumn{3}{c}{$\mathbf{2 0 1 8}^{\mathbf{a}}$} \\
\hline Rootstock & $\mathbf{N}$ & $\mathbf{P}$ & $\mathbf{K}$ & $\mathbf{N}$ & $\mathbf{P}$ & $\mathbf{K}$ \\
\hline Control (ungrafted) & $3.84 \mathrm{bc}$ & $0.53 \mathrm{bc}$ & $4.61 \mathrm{ab}$ & $4.82 \mathrm{ab}$ & 0.48 & $3.72 \mathrm{~b}$ \\
Ferro & $3.62 \mathrm{bc}$ & $0.71 \mathrm{a}$ & $4.74 \mathrm{a}$ & $4.99 \mathrm{ab}$ & 0.43 & $4.29 \mathrm{a}$ \\
VSS-61 F1 & $3.69 \mathrm{bc}$ & $0.64 \mathrm{ab}$ & $4.48 \mathrm{ab}$ & $4.73 \mathrm{~b}$ & 0.44 & $3.29 \mathrm{c}$ \\
Cobalt & $3.92 \mathrm{~b}$ & $0.62 \mathrm{ab}$ & $4.62 \mathrm{ab}$ & $5.01 \mathrm{ab}$ & 0.47 & $3.67 \mathrm{~b}$ \\
Bottle gourd & $3.48 \mathrm{c}$ & $0.62 \mathrm{ab}$ & $4.12 \mathrm{bc}$ & $5.14 \mathrm{a}$ & 0.49 & $4.03 \mathrm{a}$ \\
Super Shintoza & $4.99 \mathrm{a}$ & $0.47 \mathrm{c}$ & $4.02 \mathrm{c}$ & $5.15 \mathrm{a}$ & 0.52 & $4.15 \mathrm{a}$ \\
Prob. F & $* * *$ & $* *$ & $*$ & $*$ & ns & $*$ \\
\hline
\end{tabular}

a Different letters in the same column indicate significant differences among each group of treatments according to Duncan's test at $p<0.05{ }^{\mathrm{b}} \mathrm{ns},{ }^{*},{ }^{* *}$ indicate non-significant or significant at $p$ values $<0.05$, and $<0.01$, respectively.

The highest uptake values of $\mathrm{Si}$ were observed in the grafted plants from the rootstocks of Ferro, Cobalt, and Bottle gourd, with values significantly higher than those of the ungrafted control (Table 7). All the rootstocks had higher contents of Se in the leaves than 
the ungrafted control, except for Ferro in both years and Bottle gourd in 2017, which did not display significant differences as compared with the ungrafted control (Table 7).

Table 7. Means of silicon (Si) and selenium (Se) contents in the leaves of cucumber Gianco F1, grafted onto five cucurbit rootstocks and the ungrafted control, under heat and salinity stresses in the 2017 and 2018 seasons. Results are expressed in percentage over dry weight (Si) and $\mathrm{mg} \mathrm{kg}^{-1}$ (Se). Details on the measurement of the traits presented are provided in the Material and Methods Section.

\begin{tabular}{ccccc}
\hline & \multicolumn{2}{c}{$\mathbf{2 0 1 7}^{\mathbf{a}}$} & \multicolumn{2}{c}{$\mathbf{2 0 1 8}^{\mathbf{a}}$} \\
\hline Rootstock & $\mathbf{S i}$ & $\mathbf{S e}$ & $\mathbf{S i}$ & $\mathbf{S e}$ \\
\hline Control (ungrafted) & $6.42 \mathrm{~b}$ & $255 \mathrm{c}$ & $4.56 \mathrm{~b}$ & $279 \mathrm{c}$ \\
Ferro & $7.71 \mathrm{a}$ & $301 \mathrm{bc}$ & $5.86 \mathrm{a}$ & $308 \mathrm{bc}$ \\
VSS-61 F1 & $7.55 \mathrm{ab}$ & $507 \mathrm{a}$ & $5.70 \mathrm{ab}$ & $474 \mathrm{a}$ \\
Cobalt & $7.62 \mathrm{a}$ & $349 \mathrm{~b}$ & $5.77 \mathrm{a}$ & $406 \mathrm{ab}$ \\
Bottle gourd & $7.80 \mathrm{a}$ & $328 \mathrm{bc}$ & $6.15 \mathrm{a}$ & $402 \mathrm{ab}$ \\
Super Shintoza & $7.47 \mathrm{ab}$ & $332 \mathrm{~b}$ & $5.61 \mathrm{ab}$ & $413 \mathrm{ab}$ \\
Prob. F $\mathrm{b}$ & $*$ & $* *$ & $*$ & $* *$
\end{tabular}

$\overline{{ }^{a}}$ Different letters in the same column indicate significant differences among each group of treatments according to Duncan's test at $p<0.05 .{ }^{*} *, * *$ indicate significant at $p$ values $<0.05$, and $<0.01$, respectively.

\section{Discussion}

The establishment of net houses and greenhouses for vegetable production in arid regions of the world is increasing. For example, in Egypt, it is increasing rapidly under a national project to build nearly a million greenhouses as part of the sustainable development strategy of 2030. The intensive cultivation of cucumber plants, and other vegetables, in net houses and greenhouses in these areas is threatened by biotic and abiotic stresses that may lead to a reduction in crop productivity and quality. The production of greenhouse cucumbers in arid environments, especially in the summer, is considered to be a significant challenge, particularly in developing countries, where low-cost structure greenhouses are common. Cultivation under these conditions is often exposed to both saline soil conditions and heat stress [41,42].

We conducted a comprehensive evaluation of the response of the grafted net house cucumber plants to salinity and heat stress by measuring vegetative growth parameters, yield, fruit quality, and physiological and biochemical parameters, which included chlorophyll content, catalase and peroxidase enzymatic activities, proline contents, electrolyte leakage, and the mineral composition of leaves in both the grafted and ungrafted cucumber plants. For many traits, significant differences among treatments were observed in both years, while in others, there were differences only in one year. Repeating the experiment in two different years facilitated the identification of stable responses.

The grafting process has a crucial role in ameliorating vegetative growth under salinity and heat stress. For example, salinity stress limits cucumber growth by decreasing the photosynthetic rate and reducing the stomatal conductance, both of which are improved by grafting [43,44]. A possible explanation for this may be that the grafted plants are more vigorous and have powerful root systems, resulting in a higher water and nutrient uptake rate, greater leaf area, and higher net assimilation rate of $\mathrm{CO}_{2}$ as compared with the ungrafted plants [45]. These results provide further support for the hypothesis that the yield of net house cucumber plants under salinity and heat stress could be improved by grafting [8].

Stressed plants have different defense strategies; enzymes such as catalase, peroxidase, and superoxide dismutase, and non-enzymatic antioxidants such as proline, ascorbic acid, and glutathione, are amongst the most common defense mechanisms of plants against stresses. Other approaches for improving plant tolerance to stress include genetic engineering, cultivating stress-tolerant/resistant cultivars, exogenous application of soil amendments, mineral nutrients, microbes, osmolytes, and proper agricultural practices such as grafting. The growth of grafted net house cucumber plants is limited by soil 
properties (mainly $\mathrm{pH}$, cation exchange capacity (CEC), salinity, and the availability of nutrients), temperature, and rootstock characteristics. As we observed, grafted cucumber plants may lead to a higher biomass as compared with ungrafted plants. Concerning the mechanism for nutrient uptake and transport in grafted vegetables such as the cucumber, the mechanism is mainly controlled by communication pathways between rootstock-scion interactions, long-distance signaling, and by the rootstock genotype in grafted plants [46]. These factors may enhance grafted cucumber tolerance to nutrient toxicity or deficiency stress. We observed that grafting onto some rootstocks activated and increased catalase and peroxidase activities, while electrolyte leakage was reduced, suggesting an adaptation to the stressful conditions. Our results are in agreement with recent studies indicating that grafting can enhance the growth of net house cucumbers under salinity or heat stress [27,47], although no study has tested both stresses together.

Chlorophyll allows plants to absorb energy from light by producing essential nutritional compounds through photosynthesis. The availability of sufficient nutrients, water, atmospheric $\mathrm{CO}_{2}$, and light are required compounds for photosynthetic assimilation. Photosynthesis can be restricted because of water deficit or heat stress in arid environments, which decreases the stomatal conductance and the net photosynthetic rate. The chlorophyll content in cucumber plants has been shown to increase because of grafting under salinity, which also enhances high photosynthetic activity [43]; these findings are in agreement with our results. Ungrafted cucumber plants can suffer from a reduction in uptake of water and nutrients, which reduces water conductivity, transpiration, and the photosynthesis rate [48]. This suggests that grafting onto appropriate rootstocks can contribute to higher photosynthetic activity under combined salinity and heat stress.

Under salinity stress, many biological processes in cucumber plants are affected, ranging from photosynthetic capacity to biochemical activity [8]. These biological activities disrupt the normal metabolism of cucumber leaves and reduce water and nutrient uptake because of oxidative stress, which is the result of excessive $\mathrm{Cl}^{-}$and $\mathrm{Na}^{+}$concentrations. The results we obtained match those observed in earlier studies $[18,21,25]$ that indicated a better physiological and nutritional status in grafted plants. This is probably linked to the stronger root systems in grafted plants, which allow for the greater uptake of water and nutrients, as compared with ungrafted plants under soil salinity stress. In addition, grafting may improve nutrient uptake and translocation from root to shoot, increase leaf water content and photosynthesis capacity, and reduce $\mathrm{Na}^{+}$and/or $\mathrm{Cl}^{-}$in shoots as compared with ungrafted plants under saline conditions [21]. Cucumber growth is mainly controlled by the interaction of root temperature and nutrients [49], and therefore, grafting on an appropriate rootstock may contribute to better growth by having a stronger root system.

This study confirmed that the negative impacts of heat stress on net house cucumber growth, as also reported by Ali et al. [10], which include reductions in vegetative growth, chlorophyll content, antioxidant enzyme activities, yield, and quality, can be mitigated by grafting. The productivity of net house cucumber plants is affected by many factors, such as the environmental conditions (e.g., soil salinity, acidity, temperature, and the bioavailability of nutrients) and the rootstock. Some recent studies have investigated the effects of soil fertility [50], soil microbial communities [51], nutrient balance, and changes in soil [3] on greenhouse cucumber production. Higher temperatures as a result of climate change are projected to increase soil salinization, and therefore, the occurrence of soilborne diseases in cucumber greenhouses, as expected in environments with increased atmospheric temperature [36]. Soil salinization may also be accelerated by excessive fertilization and irrigation, which are common practices in greenhouse production systems. Previous studies on the impact of salinity stress on grafted cucumber plants $[8,18,21,52]$ have confirmed an association between salinity stress and a reduction in most physiological activities of cucumber plants (e.g., photosynthetic pigments activity, chlorophyll content, yield, and quality). Grafting could protect chlorophyll from reactive oxygen species (ROS) under salinity stress, which causes a disruption in the fine chloroplast structure and in chlorophyll stability, resulting in the oxidation of chlorophyll [8]. Our results reveal that 
VSS-61 F1 and Ferro, which are interspecific hybrids of C. maxima $\times$ C. moschata, are promising rootstocks for the grafting of cucumber plants under combined heat and salinity stress conditions, because they conferred better vegetative growth parameters to the scion, and resulted in a higher marketable fruit yield and good fruit quality. The plants grafted onto rootstock VSS-61 F1 had higher catalase activity and proline content in the leaves, which may contribute to increased tolerance to both stresses [30], while those grafted on Ferro also had higher levels of silicon in the leaves, which can play a role in better adaptation to the saline stress [23].

\section{Conclusions}

The current study showed a general positive impact of grafting on cucumber plants grown under heat stress in combination with salinity stress in net house cultivation. Although grafting, in general, provided positive results for several productive and physiological parameters, some rootstocks had a better performance than others, and cucumber plants grafted onto the rootstocks VSS-61 F1 and Ferro had the best vegetative growth and marketable fruit yield. In addition, VSS-61 F1 also had higher levels than the ungrafted control for catalase antioxidant enzyme activity, as well as for the osmolyte proline. The fact that grafted plants are vigorous and have powerful root systems probably contributed to a higher water and nutrient uptake rate, which resulted in a greater leaf area and higher net assimilation rate of $\mathrm{CO}_{2}$ as compared with ungrafted plants. The results align with those seen under studies of salinity stress alone, and reveal that grafting is a powerful agronomic practice for cucumber cultivation, not only for arid regions, but also for conditions mimicking future climate change.

Author Contributions: Conceptualization, M.R., Y.B., F.E.-A., E.-S.H. and H.E.-R.; methodology, Y.B., E.A.-A. and H.E.-R.; software, E.A.-A. and H.E.-R.; validation, Y.B., M.R. and H.E.-R.; formal analysis, E.A.-A., N.T. and H.E.-R.; investigation, E.A.-A. and F.E.-A.; resources, E.A.-A., H.E.-R. and J.P.; data curation, N.T. and M.R.; writing - original draft preparation, Y.B. and H.E.-R.; writing-review and editing, M.R., Y.B., N.T., H.E.-R., J.P. and E.-S.H.; visualization, M.R.; supervision, F.E.-A., Y.B. and E.-S.H. All authors have read and agreed to the published version of the manuscript.

Funding: This research received no external funding.

Data Availability Statement: The data presented in this study are available on request from the corresponding author.

Acknowledgments: The authors are thankful to Hannah Joy Kennedy and Margit Olle for revising the English text. The authors thank the staff members of the Physiology and Breeding of Horticultural Crops Laboratory, Department of Horticulture, Faculty of Agriculture, Kafrelsheikh University, Kafr El-Sheikh (Egypt) for conducting most of the tests, as they helped in completing this work. This research did not receive any specific grant from funding agencies in the public, commercial, or non-profit sectors.

Conflicts of Interest: The authors declare no conflict of interest.

\section{References}

1. Pereira, B.J.; Filho, A.B.C.; La Scala, N. Greenhouse gas emissions and carbon footprint of cucumber, tomato and lettuce production using two cropping systems. J. Clean. Prod. 2021, 282, 124517. [CrossRef]

2. Wei, Y.; Wang, Y.; Wu, X.; Shu, S.; Sun, J.; Guo, S. Redox and thylakoid membrane proteomic analysis reveals the momordica (Momordica charantia L.) rootstock-induced photoprotection of cucumber leaves under short-term heat stress. Plant Physiol. Biochem. 2019, 136, 98-108. [CrossRef]

3. Fan, Y.; Zhang, Y.; Hess, F.; Huang, B.; Chen, Z. Nutrient balance and soil changes in plastic net-house vegetable production. Nutr. Cyc. Agroecosys. 2020, 117, 77-92. [CrossRef]

4. Phogat, V.; Mallants, D.; Cox, J.W.; Šimůnek, J.; Oliver, D.P.; Awad, J. Management of soil salinity associated with irrigation of protected crops. Agric. Water Manag. 2020, 227, 105845. [CrossRef]

5. Tiwari, R.K.; Lal, M.K.; Kailash Chandra Naga, K.C.; Kumar, R.; Chourasia, K.N.; Subhash, S.; Kumar, D.; Sharma, S. Emerging roles of melatonin in mitigating abiotic and biotic stresses of horticultural crops. Sci. Hort. 2020, 272, 109592. [CrossRef] 
6. Nie, W.; Gong, B.; Chen, Y.; Wang, J.; Wei, M.; Shi, Q. Photosynthetic capacity, ion homeostasis and reactive oxygen metabolism were involved in exogenous salicylic acid increasing cucumber seedlings tolerance to alkaline stress. Sci. Hort. 2018, 235, 413-423. [CrossRef]

7. Li, C.; Bian, B.; Gong, T.; Liao, W. Comparative proteomic analysis of key proteins during abscisic acid-hydrogen peroxide-induced adventitious rooting in cucumber (Cucumis sativus L.) under drought stress. J. Plant Physiol. 2018, 229, 185-194. [CrossRef] [PubMed]

8. Elsheery, N.I.; Helaly, M.N.; Omar, S.A.; John, S.V.S.; Zabochnicka-Swiątek, M.; Kalaji, H.M.; Rastogi, A. Physiological and molecular mechanisms of salinity tolerance in grafted cucumber. S. Afr. J. Bot. 2020, 130, 90-102. [CrossRef]

9. Zhang, T.; Shi, Z.; Zhang, X.; Zheng, S.; Wang, J.; Mo, J. Alleviating effects of exogenous melatonin on salt stress in cucumber. Sci. Hort. 2020, 262, 109070. [CrossRef]

10. Ali, A.H.; Abdelrahman, M.; Radwan, U.; El-Zayat, S.; El-Sayed, M.A. Effect of Thermomyces fungal endophyte isolated from extreme hot desert-adapted plant on heat stress tolerance of cucumber. Appl. Soil Ecol. 2018, 124, 155-162. [CrossRef]

11. Pandey, P.; Ramegowda, V.; Senthil-Kumar, M. Shared and unique responses of plants to multiple individual stresses and stress combinations: Physiological and molecular mechanisms. Front. Plant Sci. 2015, 6, 723. [CrossRef] [PubMed]

12. Thomas-Barry, G.; Martin, C.S.; Lynch, M.D.J.; Ramsubhag, A.; Miller, J.; Charles, T.C. Driving factors influencing the rhizobacteriome community structure of plants adapted to multiple climatic stressors in edaphic savannas. Sci. Total Environ. 2021, 769, 145214. [CrossRef]

13. Isah, T. Stress and defense responses in plant secondary metabolites production. Biol. Res. 2019, 52, 39. [CrossRef]

14. Singh, R.K.; Singh, A.; Zander, K.K.; Mathew, S.; Kumar, A. Measuring successful processes of knowledge co-production for managing climate change and associated environmental stressors: Adaptation policies and practices to support Indian farmers. $J$. Environ. Manag. 2021. [CrossRef]

15. Tomaz de Oliveira, M.M.; Lu, S.; Zurgil, U.; Raveh, E.; Tel-Zur, N. Grafting in Hylocereus (Cactaceae) as a tool for strengthening tolerance to high temperature stress. Plant Physiol. Biochem. 2021, 160, 94-105. [CrossRef]

16. Bithell, S.L.; Condè, B.; Traynor, M.; Donald, E.C. Grafting for soilborne disease management in Australian vegetable production systems-a review. Australas. Plant Pathol. 2013, 42, 329-336. [CrossRef]

17. Reddy, P.P. Grafted vegetables for management of soilborne pathogens. In Sustainable Crop. Protection under Protected Cultivation; Reddy, P.P., Ed.; Springer Nature: Singapore, 2016; pp. 83-97. [CrossRef]

18. Usanmaz, S.; Abak, K. Plant growth and yield of cucumber plants grafted on different commercial and local rootstocks grown under salinity stress. Saudi J. Biol. Sci. 2019, 26, 1134-1139. [CrossRef] [PubMed]

19. Wang, Q.; Men, L.; Gao, L.; Tian, Y. Effect of grafting and gypsum application on cucumber (Cucumis sativus L.) growth under saline water irrigation. Agric. Water Manag. 2017, 188, 79-90. [CrossRef]

20. Al-Harbi, A.R.; Al-Omran, A.M.; Alharbi, K. Grafting improves cucumber water stress tolerance in Saudi Arabia. Saudi J. Biol. Sci. 2018, 25, 298-304. [CrossRef]

21. Sallaku, G.; Sandén, H.; Babaj, I.; Kaciu, S.; Balliu, A.; Rewald, B. Specific nutrient absorption rates of transplanted cucumber seedlings are highly related to RGR and influenced by grafting method, AMF inoculation and salinity. Sci. Hort. 2019, 243, 177-188. [CrossRef]

22. Ivushkin, K.; Bartholomeus, H.; Bregt, A.K.; Pulatov, A.; Kempen, B.; de Sousa, L. Global mapping of soil salinity change. Remote Sens. Environ. 2020, 111, 111260. [CrossRef]

23. Zhu, Y.; Jiang, X.; Zhang, J.; He, Y.; Zhu, X.; Zhou, X.; Gong, H.; Yin, J.; Liu, Y. Silicon confers cucumber resistance to salinity stress through regulation of proline and cytokinins. Plant Physiol. Biochem. 2020, 156, 209-220. [CrossRef]

24. Alpaslan, M.; Gunes, A. Exploring the communities of bacteria, fungi and ammonia oxidizers in rhizosphere of Fusarium-diseased greenhouse cucumber. Plant Soil 2001, 236, 123-128. [CrossRef]

25. Huang, Y.; Bie, Z.; He, S.; Hua, B.; Zhen, A.; Liu, Z. Improving cucumber tolerance to major nutrients induced salinity by grafting onto Cucurbita ficifolia. Environ. Expt. Bot. 2010, 69, 32-38. [CrossRef]

26. Van Velthuizen, H.; Huddleston, B.; Fischer, G.; Salvatore, M.; Ataman, E.; Nachtergaele, F.O.; Zanetti, M.; Bloise, M.; Antonicelli, A.; Bel, J.; et al. Mapping Biophyical Factors That Influence Agricultural Production and Rural Vulnerability; Food and Agriculture Organization of the United Nations: Rome, Italy; International Institute for Applied Systems Analysis: Rome, Italy, 2007; pp. 1-84.

27. Wang, Y.; Guo, S.; Wang, L.; Wang, L.; He, X.; Shu, S.; Sun, J.; Lu, N. Identification of microRNAs associated with the exogenous spermidine-mediated improvement of high-temperature tolerance in cucumber seedlings (Cucumis sativus L.). BMC Genom. 2018, 19, 285. [CrossRef] [PubMed]

28. Xu, Y.; Yuan, Y.; Du, N.; Wang, Y.; Shu, S.; Sun, J.; Guo, S. Proteomic analysis of heat stress resistance of cucumber leaves when grafted onto Momordica rootstock. Hort. Res. 2018, 5, 53. [CrossRef]

29. Parvathi, M.S.; Dhanyalakshmi, K.H.; Nataraja, K.N. Molecular mechanisms associated with drought and heat tolerance in plants and options for crop improvement for combined stress tolerance. In Agronomic Crops; Hasanuzzaman, M., Ed.; Springer Nature: Singapore, 2020; pp. 481-502. [CrossRef]

30. Lopez-Delacalle, M.; Silva, C.J.; Mestre, T.C.; Martinez, V.; Blanco-Ulate, B.; Rivero, R.M. Synchronization of proline, ascorbate and oxidative stress pathways under the combination of salinity and heat in tomato plants. Environ. Expt. Bot. 2021, $183,104351$. [CrossRef] 
31. Apel, K.; Hirt, H. Reactive oxygen species: Metabolism, oxidative stress, and signal transduction. Annu. Rev. Plant Biol. 2004, 55, 373-399. [CrossRef]

32. Brenes, M.; Pérez, J.; González-Orenga, S.; Solana, A.; Boscaiu, M.; Prohens, J.; Plazas, M.; Fita, A.; Vicente, O. Comparative studies on the physiological and biochemical response of salt stress of eggplant (Solanum melongena) and its rootstock S. torvum. Agriculture 2020, 10, 328. [CrossRef]

33. Sevgican, A. Örtüaltı Sebzeciliği ; Ege Üniversitesi Ziraat Fakültesi Yayınları: İzmir, Turkey, 2002; pp. 1-476.

34. Upadhyaya, A.; Sankhla, D.; Davis, T.D.; Sankhla, N.; Smith, B.N. Effect of paclobutrazol on the activities of some enzymes of activated oxygen metabolism and lipid peroxidation in senescing soybean leaves. J. Plant Physiol. 1985, 121, 453-461. [CrossRef]

35. Rao, M.V.; Paliyath, C.; Ormrod, D.P.; Murr, D.P.; Watkins, C.B. Influence of salicylic acid on $\mathrm{H}_{2} \mathrm{O}_{2}$ production, oxidative stress and $\mathrm{H}_{2} \mathrm{O}_{2}$-metabolizing enzymes: Salicylic acid-mediated oxidative damage requires $\mathrm{H}_{2} \mathrm{O}_{2}$. Plant Physiol. 1997, 115, 137-149. [CrossRef]

36. Bates, L.S.; Waldren, R.P.; Teare, I.D. Rapid determination of free proline for water-stress studies. Plant Soil 1973, 39, 205-207. [CrossRef]

37. Lutts, S.; Kinet, J.M.; Bouharmont, J. Changes in plant response to $\mathrm{NaCl}$ during development of rice (Oryza sativa L.) varieties differing in salinity resistance. J. Exp. Bot. 1995, 46, 1843-1852. [CrossRef]

38. Dai, W.; Zhang, K.Q.; Duan, B.W.; Sun, C.Z.; Zheng, K.L.; Cai, R.; Zhuang, J.Y. Rapid determination of silicon content in rice. Rice Sci. 2005, 12, 145-147.

39. Hawrylak-Nowak, B. Comparative effects of selenite and selenate on growth and selenium accumulation in lettuce plants under hydroponic conditions. Plant. Growth Regul. 2013, 70, 149-157. [CrossRef]

40. Snedecor, G.W.; Cochran, W.G. Statistical Methods, 8th ed.; Iowa State University Press: Ames, IA, USA, 1989 ; pp. 1-491.

41. Cui, B.-J.; Niu, W.-Q.; Du, Y.D.; Zhang, Q. Response of yield and nitrogen use efficiency to aerated irrigation and $\mathrm{N}$ application rate in net-house cucumber. Sci. Hort. 2020, 265, 109220. [CrossRef]

42. Dong, J.; Gruda, N.; Li, X.; Tang, Y.; Zhang, P.; Duan, Z. Sustainable vegetable production under changing climate: The impact of elevated $\mathrm{CO}_{2}$ on yield of vegetables and the interactions with environments-A review. J. Clean. Prod. 2020, 253, 119920. [CrossRef]

43. Rouphael, Y.; Cardarelli, M.; Rea, E.; Colla, G. Improving melon and cucumber photosynthetic activity, mineral composition, and growth performance under salinity stress by grafting onto Cucurbita hybrid rootstocks. Photosynthetica 2012, 50, 180-188. [CrossRef]

44. Fan, H.F.; Ding, L.; Xu, Y.L.; Du, C.X. Antioxidant system and photosynthetic characteristics responses to short-term PEG-induced drought stress in cucumber seedling leaves. Russ. J. Plant Physiol. 2017, 64, 162-173. [CrossRef]

45. Amaro, A.C.E.; Macedo, A.C.; Ramos, A.R.P.; Goto, R.; Ono, E.O.; Rodrigues, J.D. The use of grafting to improve the net photosynthesis of cucumber. Theor. Exp. Plant Physiol. 2014, 26, 241-249. [CrossRef]

46. Lu, X.; Liu, W.; Wang, T.; Zhang, J.; Li, X.; Zhang, W. Systemic long-distance signaling and communication between rootstock and scion in grafted vegetables. Front. Plant Sci. 2020, 11, 460. [CrossRef] [PubMed]

47. Li, H.; Liu, S.S.; Yi, C.Y.; Wang, F.; Zhou, J.; Xia, X.J.; Shi, K.; Zhou, Y.H.; Yu, J.Q. Hydrogen peroxide mediates abscisic acid-induced HSP70 accumulation and heat tolerance in grafted cucumber plants. Plant Cell Environ. 2014, 37, 2768-2780. [CrossRef] [PubMed]

48. Giné, A.; González, C.; Serrano, L.; Sorribas, F.J. Population dynamics of Meloidogyne incognita on cucumber grafted onto the Cucurbita hybrid RS841 or ungrafted and yield losses under protected cultivation. Eur. J. Plant. Pathol. 2017, 148, 795-805. [CrossRef]

49. Yan, Q.; Duan, Z.; Mao, J.; LI, X.; Dong, F. Low root zone temperature limits nutrient effects on cucumber seedling growth and induces adversity physiological response. J. Integr. Agric. 2013, 12, 1450-1460. [CrossRef]

50. Wang, Z.; Gong, D.; Zhang, Y. Investigating the effects of net-house vegetable cultivation on soil fertility in Lhasa, Tibetan Plateau. Chin. Geogr. Sci. 2020, 30, 456-465. [CrossRef]

51. Zhao, Y.; Mao, X.; Zhang, M.; Yang, W.; Di, H.J.; Ma, L.; Liu, W.; Li, B. Response of soil microbial communities to continuously mono-cropped cucumber under net-house conditions in a calcareous soil of north China. J. Soils Sediments 2020, 20, $2446-2459$. [CrossRef]

52. Alsaeedi, A.; El-Ramady, H.; Alshaal, T.; El-Garawany, M.; Elhawat, N.; Al-Otaib, A. Silica nanoparticles boost growth and productivity of cucumber under water deficit and salinity stresses by balancing nutrients uptake. Plant Physiol. Biochem. 2019, 139, 1-10. [CrossRef] 